\title{
Capability components of supply chain resilience for readymade garments (RMG) sector in Bangladesh during COVID-19
}

Supply chain resilience for $\mathrm{RMG}$

Mohammad Ali and Syed Mahbubur Rahman American international University-Bangladesh (AIUB), Dhaka, Bangladesh, and Guilherme F. Frederico School of Management, Federal University of Paraná (UFPR), Curitiba, Brazil

\begin{abstract}
Purpose - The readymade garments (RMG) industry acts as one of the foremost vital catalysts for financial as well as social advancement of Bangladesh. Due to the harsh impact of COVID-19, RMG sector has been confronting a never-seen-before phenomenon. Since the supply chain has seriously been influenced, concern raises among industry and policymakers on how to support against disturbances resulting from pandemics. Accordingly, this research aims to explore the vulnerability and capability factors of RMG sector in Bangladesh, their relationship and how these variables affect supply chain resilience.

Design/methodology/approach - A qualitative research design has been employed. In the first stage, content analysis has been performed. Since COVID-19 is a new experience, newspapers were the source to become acquainted with the vulnerability and capability factors following the guidelines provided by Pettit et al. (2010). In the second stage, in-depth interviews with key informants were conducted to investigate the relationship among the variables and how these factors may influence supply chain resilience.

Findings - This study identifies fourteen capability factors and their sub-factors of RMG industry in Bangladesh in order to improve the resilience capacity against the vulnerabilities in the context of COVID-19 pandemic.

Research limitations/implications - This research is based on the setting of particular industry in Bangladesh, where respondents are immersed in a unique culture. Special care is required to generalize the results to other segments and phenomena.

Practical implications - The framework recognizes the balanced and unbalanced strength with the capability's components and find the relation between capabilities and vulnerabilities within the fashion industry. By creating the resilience network with the four conceivable positions, companies can find themselves with their capability's components and natural vulnerabilities.

Originality/value - This study investigates diverse components of capability figure against vulnerabilities to create the supply chain resilience. This paper, moreover, develops with four conceivable positions with their capabilities against existing vulnerabilities which brings timely contribution considering the context of COVID-19.
\end{abstract}

Keywords Readymade garments (RMG), Bangladesh, Supply chain, Resilience, Capability, Vulnerability Paper type Case study

\section{Introduction}

Although the mankind has significant history of being infected by virus, the recent and the ongoing observation and the evidence of infections through the spread of COVID-19 have

(C) Mohammad Ali, Syed Mahbubur Rahman and Guilherme F. Frederico. Published in Modern Supply Chain Research and Applications. Published by Emerald Publishing Limited. This article is published under the Creative Commons Attribution (CC BY 4.0) license. Anyone may reproduce, distribute, translate and create derivative works of this article (for both commercial and non-commercial purposes), subject to full attribution to the original publication and authors. The full terms of this license may be seen at http://creativecommons.org/licences/by/4.0/legalcode

Received 20 June 2020 Revised 14 October 2020 6 March 2021

Accepted 8 April 2021 
MSCRA

3,2

128

already surpassed most of the historical evidences both in magnitude and destruction. China was the first infected country in the world. After the first infection with an unknown cause, reported in December 2019 in the Central Hospital of Wuhan, the virus spread all over the world causing death of more than four million lives, as of early May and still continuing (Wu et al., 2020). The World Health Organization (WHO) (2020) declared global pandemic due to the spread of virus and termed it as coronavirus disease 2019 (COVID-19). The COVID-19 has infected more than 200 countries and territories in the world. This uneven spread has affected business and commerce all over the world and the overall GDP loss estimated to be up to couple of trillions of dollars (McKibbin and Fernando, 2020). Bangladesh is no different and is emerged on this scenario. Readymade garments (RMG) industry has been facing massive challenges, since many buyers have canceled bulk volume of orders due to unexpected spread and consequences of COVID-19.

From a debut export of merely couple of tens of thousands dollar in the late 70s, RMG sector in Bangladesh reached a USD30.61 billion export in 2017-18 fiscal year, which accounted for around $83 \%$ of the total export earnings of the country (Khan and Milne, 2019; BGMEA, 2020). Apparel export of Bangladesh has more than tripled since 2008, and in 2019, it was valued at more than USD34 billion (BGMEA, 2020). It is the second-largest global finished apparel exporter followed by China. From less than 800 before 1990 the number of factories in Bangladesh has grown to more than 5,000 in 2009; and with some ups and downs, the number of factories remains around 5,000 by the beginning of 2020 (BGMEA, 20200). The RMG sector acts as one of the most important catalysts for economic as well as social development of Bangladesh. Due to sudden attack by COVID-19 and corresponding reactions by the buyers, RMG has been facing a never-seen-before consequence. Since the supply chain has severely been affected, concern raises among industry and policymakers how to sustain against this current and future disruptions.

A supply chain is the arrangement of organizations, their offices, capacities and activities that are included in creating and conveying an item or service. A strong supply chain promotes a leading position, where all the stakeholders from different stages of supply chain management (SCM) move fast in the fast fashion era (Stevenson and Sum, 2014). RMG sector in Bangladesh, particularly the compliance factories, has moved into a competitive and challenging platform where it ensures high quality product at low-cost and a shortest possible lead time. Organizations are turning progressively to worldwide resources for their generation components to attain competitive preferences (Uddin and Akhter, 2019)

The factories continuously strive for adapting to effective SCM in order to provide the products as per the requirements. However, most of the factories in Bangladesh are unclear about the SCM due to the lack of understanding and its importance (Hossain, 2019). Since the industry is moving toward Supply Chain 4.0 (Frederico et al., 2019; Büyüközkan and Göçer, 2018), transparency in supply chain across the apparel industry is a prerequisite to remain competitive in the global market (Hossain, 2019). Besides this continuous pressure, COVID-19 poses an extra burden. Numerous people in Bangladesh do not have sufficient savings, so that they would not be able to endure the current circumstance (Sakamoto et al., 2020). More than one million garment workers in Bangladesh have as of now been terminated due to arrangement cancelations and the disappointment of buyers to pay for these cancelations (Sakamoto et al., 2020). In case of a widespread crisis, RMG segments showed up to have no protect bundles to cover the pay rates of workers and instantly looked for government help for paying them (Biswas et al., 2020).

COVID-19 has already started to impact the global economy. Many countries have enforced lockdown. The apparel sector has to bear the shock of the ongoing coronavirus outbreak. The disruption started from January 2020 when China, the home of a lot of raw material imports, restricted export due to the pandemic effects. The apparel industry in Bangladesh was in operation with around two-month raw material inventory storage. However, since the 
beginning of March most of the buyers were gradually canceling their orders as well as postponing the on-going production, especially those from the COVID-19 infected western countries (FEAR WEAR, 2020). Mentionable European brands like Primark, Inditex and H\&M as well as major retailers from North America, such as Nike, Columbia Sportswear and GAP, have already shut down their outlet due to countrywide lockdown (FEAR WEAR, 2020). Hence, orders were being canceled and finished products were not being shipped through either ship or air. Factories and the workforce are under threat of existence. As of the end of April 2020, the loss of order cancellation was $\$ 3.16$ billion, while the canceled volume of shipment amounted 979 million pieces (BGMEA, 2020). At least 1,140 factories with more than 2.25 million workers are struggling to cope or survive (BGMEA, 2020).

In Bangladesh, it is anticipated that around six billion in trade income will be misplaced amid this monetary year in the midst of cancellations from a few of the world's biggest brands and retailers (Sen et al., 2020). Factories have been forced close in response to the government implemented lockdowns, although has termed as general holiday, in the country and due to canceled orders or requests to delay the payment by giant brands. Many factory owners were not able to pay workers as repetitive cancellation of orders took place, which led to labor unrest in many factories as well (FEAR WEAR, 2020). Many factories announced layoffs at their units apparently following the enacted labor laws. According to the worker's rights group, around 10,000 workers have been terminated from different locations from different factories in Dhaka, Gazipur, Savar, Narayanganj and Chattogram. The brands and retailers not as it were canceling the buying orders but moreover denied requiring responsibility for articles of clothing and the workers didn't get their compensations (Kelly, 2020).

As for the many segments of industry, the several impacts suffered in wear industry due to COVID-19 pandemic has been encouraging researchers to study the resilience aspects of those supply chains which this study brings as the purpose, especially in the context of RMG industry in Bangladesh.

Some researchers (e.g. De Sousa Jabbour et al., 2020; Van Hoek, 2020) have called attention to develop new researches deployment amid the COVID-19 context. Then, this study explores capability components against vulnerabilities of the RMG sector in Bangladesh. Although a good number of researches has concentrated on RMG, a structured set of vulnerability and capability factors is yet to be developed, which this study fulfills. Besides, there is limited study about resilience factors amid COVID-19, particularly focusing RMG. Hence, this study might be replicable in similar industries in other countries. The Rana Plaza building collapse which may be a large-scale calamity to hit the worldwide industry briefly disturbed prevailing stories environment the worldwide production network (Brydges and Hanlon, 2020). There's a have to be use innovation and advancement to adjust existing nearby fabricating capabilities in Cambodia amid the widespread crisis toward much-needed medical hardware and personal protective equipment for household utilization and trade (Banga and te Velde, 2020). Manufacturing firms require modifying the settings to compete within the current unstable and eccentric setting (Napoleone and Prataviera, 2020).

The rests of the paper are organized as takes after: Section 2 discuss background of the problem and expounds a few areas of the theoretical background. Section 3 discuss the methodology followed by empirical specification. Section 4 discuss the results on the resilience factors taken after by interviews and content analysis. Section 5 discussion based on the results, and section 6 concludes the paper.

\section{Theoretical background}

\subsection{RMG sector of Bangladesh}

The RMG sector of Bangladesh employs more than 4.4 million people, among whom $80-90 \%$ is female, and this is an indication of the sector's contribution toward woman empowerment 
MSCRA

3,2
(Akhter et al., 2019; Talapatra et al., 2019). In total, 80\% of Bangladesh's exports and around $12 \%$ of GDP come from ready-made garment sector, which is the biggest manufacturing division in Bangladesh (Menzel and Woodruff, 2019). The garments sector drastically expanded the share of women working in full-time wage occupations, as growth compounding at a yearly rate of around 15\% more than two decades (Menzel and Woodruff, 2019). Majority of the RMG producers are small and medium size enterprises; nearly three-fourths of the factories have less than 500 employees (Talapatra et al., 2019). Most of the factories are located in Dhaka, the capital, with few in nearby Narayanganj and some in the port city Chattogram (former Chittagong) (Talapatra et al., 2019). Of export volume, 60\% of the contracts are with the brands from European buyers and the rest with American buyers. The common categories of the products are woven, knitwear, denim and sweater.

Retailers from North America and Europe who source the products from Bangladesh have adopted an innovative approach to improve the working condition by developing the consortium of alliance for Bangladesh workers safety and accord for fire and building safety in Bangladesh (Liu et al., 2019). Government, local and international initiatives along with the accord and alliance in Bangladesh, a cluster has been developed by the global trade union federations, nongovernment organization (NGO) and also multinational apparel companies. They have been working together to improve the internal environment of the factory to make a safer place for workers and to create a better image (Ashraf and Prentice, 2019). The comparative advantages of Bangladeshi RMG industry include low wages, long working hours, extreme overtime, less employment security for the global brands and retailers (Ashraf and Prentice, 2019). Those initiatives have generated more interests on studies related to the RMG industry's supply chain, in order to enhance its performance and sustainability requirements to the market. With the COVID-19 event, the resilience aspect has also begun to be considered as one of the relevant subjects of investigation for the RMG industry.

\subsection{Conceptualizing supply chain resilience}

Based on an extensive review, Jüttner and Maklan (2011) have summarized four supply chain resilience capabilities: flexibility, velocity, visibility and collaboration, which are strongly impacted by disruptions. During crisis time, for instance in financial crisis, flexibility helps organization switch to alternative cost-effective supply sources; velocity assists in finding unexplored regional demands; visibility helps organization judge the supply chain by sharing information to prepare any potential delivery failure; and collaboration throughout the chain ensure smooth functioning (Jüttner and Maklan, 2011). These capabilities seem equally influential during pandemic like COVID-19. When one or more components of the network like supply of raw materials, production, demand, distribution or transportation become unavailable and as a result it is prompt negative impacts on the supply chain network (Paul and Chowdhury, 2020). It is clearly appearing a require for advancing the supply chain resilience research and practices amid the uncommon and extra-ordinary circumstance due to the COVID-19 outbreak (Ivanov and Dolgui, 2020).

Van Hoek (2020) helps endeavors to center on openings to shut the crevice between supply chain resilience inquire about and industry hone. More focused on, less conceptual and more experimental investigate into occasions encompassing COVID-19 can offer assistance supervisors resolve supply chance challenges and can offer assistance decrease the chance of requiring assisting relearn lessons as of now learned in investigate when the following emergency comes around. (Van Hoek, 2020). The journey toward building up flexibility in supply chains requires structured state of intellect toward danger assessment, joint and common purposes between peoples and the intrigued of resilience and viable streams of materials and information (De Sousa Jabbour et al., 2020). In practical, supply chains, which are looking to end up 4.0 era, are those which can be stronger by the enhancement of higher 
responsiveness, what can create a better response against conceivable disturbances from COVID-19 episode (Frederico, 2020). Yet, disruptive technologies such as big data analytics plays crucial role on the supply chain resilience (Papadopoulos et al., 2017). Brusset and Teller (2017) recommend that's to supply bits of information for fulfilling versatility by mapping the associations between the sharpens, assets and shapes over which a chief has control.

Organizations and their supply chains must create both proactive and responsive flexible capabilities to extend a specific level of availability, reaction and recuperation capacity amid the pre-disaster and post-disaster stages (Chowdhury and Quaddus, 2017). Papadopoulos et al. (2017) suggest that the comes about of the investigation recommend that swift trust, in-arrangement sharing and public private organization are basic enablers of resilience in supply chain system. A firm with a more inventive environment straightforwardly or by implication, influence to a more resilience to disturbance (Sabahi and Parast, 2019). Ivanov and Dolgui (2020) suggest that when resistance to extraordinary disruptions must be considered at the scale of reasonability, a new angle of supply chain resilience research is very critical. For the garments sector growth in future, both the government and private sector of Bangladesh ought to fortify updating by including of its special benefits (Ahmed, 2009). Garment workers will confront the long-lasting impacts especially related to their healthissues, monetary hardship and failure to pay for fundamentals such as food and future employment opportunities during COVID-19 pandemic (Kabir et al., 2020).

The flexibility of the supply chain depends on the capability of the person involved on its management and on the broader arrangement indeed counting competitors (Scholten $e t$ al., 2019). Buyer's discernments of supply disturbance probability are emphatically related to their selection of buffer and process-oriented hazard relief strategies and inclination for process-oriented chance moderation strategies (Vanpoucke and Ellis, 2019). Digital technology can bolster the capability for the concerning the part of resilience practice in progressing patient safety (Rubbio et al., 2019). Resilience does not depend on all organizations within the supply chain but or maybe on the company able to reconfigure the assets to control for the disruption (De Sá et al., 2019).

Jüttner and Maklan (2011) observed that if supply chain resilience decreases the negative consequences of supply chain risk events by ensuring recovery to a better state or the equivalent previous state at least, it should have the potential to decrease vulnerability of supply chain. However, the authors observed that highly vulnerable supply chain may have resilience of any extent, which implies high or low resilience is not necessarily related to the level of vulnerability. Pettit et al. (2010) have argued that not necessarily a returning to predisruption supply chain after disruption would be beneficial rather learning how to adapt may be worthy. Researchers from different disciplines are broadly centering their considerations for resilience because it could be a multi-disciplinary concept (Hosseini et al., 2019). Pre-disruption and post-disruption are included in the resilience which is principal perspectives of disaster preparedness and emergency management (Pettit et al., 2019).

Lee (2004) suggested raising three supply chain qualities, commonly known as the TripleA Supply Chain: agility, adaptability and alignment in order to achieve sustainable competitiveness even after any disruption. Christopher and Peck (2004, cited in Pettit et al., 2010) have suggested four key principles through which supply chain resilience could be created: (1) resilience can be built into a system before a disruption takes place, (2) need for a high level of collaboration to identify and manage risks, (3) quick reaction to unforeseen events and (4) a culture of risk management.

\subsection{Current context of RMG sector during COVID-19}

The primary initiative government took to address spread of novel COVID-19 was declaring a general holiday which compelled the garments factories to close down immediately on March
Supply chain resilience for RMG 
MSCRA

3,2
24,2020 . The government has requested the owners not to terminate workers. By the end of March 2020, government announced the impetus package of BDT500 billion (equivalent USD 6.25 billion) to help the industry to minimize the impacts from sudden shut down and cancellation of orders. This financial support was intended for the continuation of wages for labors for up to three months. Factory owners are supposed to use this benefit of funding from the stimulus package at the annual rate of two percent. The precondition for availing the fund also included payment of salaries and wages made either to a bank or mobile phone account directly by the government involving Bangladesh Bank, the central bank. In doing so, the manufacturer has to provide the evidence with the salary sheet, workers list and the account number to the disbursing authority. The factory gets six-months of grace period where repayment would start from the seventh month of receiving the money. There were some private initiatives as well, for instance HSBC Bangladesh announced a short-term loan up to one year with a principal moratorium for four months for the owner of the garments which could be used to support miscellaneous payments. Since HSBC does not allow the moratorium period for more than four months, clients do not require to pay any installment within the time and during the crisis moment. The central bank has urged other commercial banks to come up with similar support. Besides, government has also sought USD one billion from the International Monetary Fund (IMF) and the World Bank. The Industriall Bangladesh Council (IBC) has ensured government about workers payment and safety against COVID-19. Government, BGMEA and IBC are monitoring these activities under the leadership of the labor ministry.

On regards supply chain resilience, COVID-19 has put supply chains in a vulnerable situation. Not unlike, RMG industry has been immersed in an unstable environment, with vulnerabilities testing its supply chains, being an unique opportunity to learn how it is being performed amid this recent reality.

\subsection{Supply chain vulnerability}

Supply chains are becoming more complex as a result of environmental change and globalization, and hence, in order to apprehend the dynamics of turbulence and complexity in supply chain, supply chain resilience research requires a holistic view (Pettit et al., 2010). Supply chain risk management attempts to reduce supply chain vulnerability, while supply chain resilience aims to develop adaptive capacities to prepare for unexpected events and to respond to and recover from subsequent disruptions (Jüttner and Maklan, 2011; Ponomarov and Holcomb, 2009). Supply chain resilience management is a proactive tool which has the potential to complement and enhance usual risk management of organization, although not all risks are preventable (Petit et al., 2010; Jüttner and Maklan, 2011). Pettit et al. (2010) have argued that the foundation of supply chain resilience depends on how to deal with the factors resulting in supply chain disruptions including among others globalized supply chains, specialized factories, increased outsourcing, increased volatility of demand and technological innovations. Supply chain managers are becoming more concerned about vulnerabilities arises from such disruptions although there are instances where disruptions bring opportunities. In order to enhance the performance of supply chains amid those vulnerabilities, it is relevant to understand the aspects related to the capabilities of supply chain's resilience.

\subsection{Supply chain resilience capability}

In order to perform well both under normal scenario and in quick recovery after disruptions, Tang (2006) suggested nine supply chain strategies: postponement, strategic stock, flexible supply base, make-and-buy, economic supply incentives, flexible transportation, revenue management, dynamic assortment planning and silent product rollover. As an extension, Pettit et al. (2010) have proposed a broader view and explained that supply chain resilience increases as capabilities increase and vulnerabilities decrease (Figure 1), hence, providing 


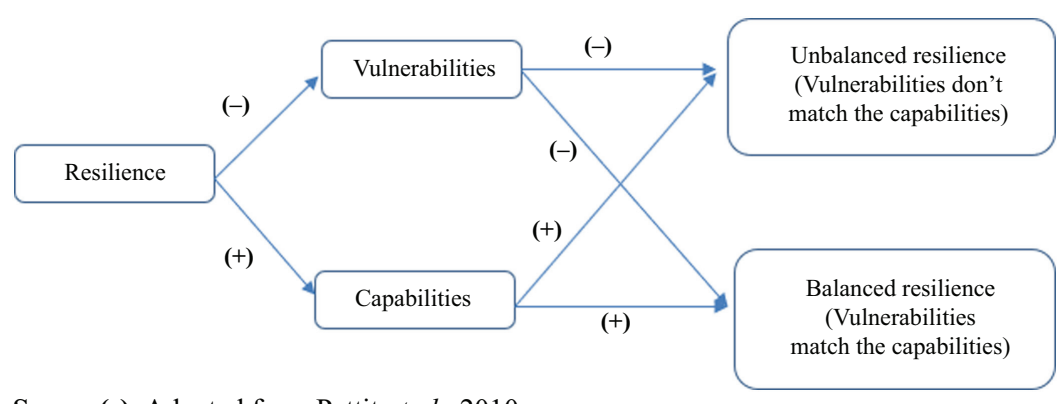

Supply chain resilience for RMG

Source(s): Adapted from Pettit et al., 2010

two factors for intensive concentration: vulnerability and capability. Developing capabilities that best suits overcoming vulnerability of the supply chain creates a state of balance between investment and risk, referred as "balanced resilience" while eroded profitability and excessive risk are the unbalanced resilience.

Supply chain resilience, a multidimensional and hierarchical construct, consists of three primary dimensions: proactive capability, reactive capability and supply chain design quality (Chowdhury and Quaddus, 2017). Twelve sub-dimensions of these three primary dimensions operationalize the supply chain. Chowdhury and Quaddus (2017) has argued that the supply chain resilience scale better predicts supply chain operational vulnerability and performance, which also conforms fitness criteria of dynamic capability theory.

In terms of measurable variables, supply chain resilience framework is the first to define resilience (Pettit, 2010). Pettit (2010) has identified that the framework recognizes the need to balance managerial capabilities with the inherent vulnerabilities of the supply chain design and environment in which it operates. The author has also identified 14 unique capabilities which contribute to increasing a supply chain's level of resilience. Carvalho et al. (2012) has proposed a mapping framework to improve supply chain resilience, which allows identification of existing supply chain operation and possible transition states, together with points of vulnerability.

While factories would clearly incline toward to have a high capacity for both capability and vulnerability, it is more likely that companies will have a mix of these qualities. In particular, given asset goals and competitive components, companies ought to select where it is best for them to contribute constrained resources. Figure 2 shows the matrix for capability

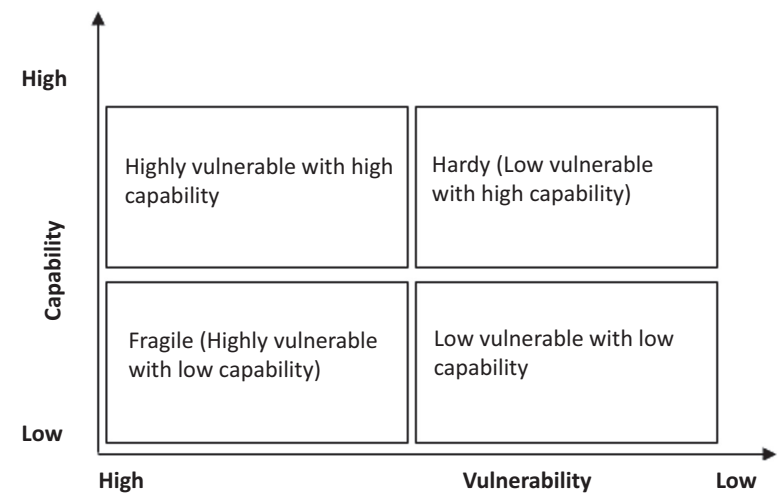

Figure 2.

Matrix for measurement of resilience

Source(s): Adapted from Steven et al., 2015 
MSCRA

3,2

134

Table 1. Interviews and information details and vulnerability, which characterizes conceivable position that companies might find itself in with regard to changed levels of these characteristics.

\section{Research method}

The research strategy herein proposed is qualitative in nature, considering that it aims to explore RMG industry resilience in Bangladesh amid COVID-19 pandemic. As a research method, case study was chosen. According to Bryman and Bell (2007) case study is one of the most research methods used in a qualitative strategy. Voss et al. (2002) state that a case study is a description of a phenomenon, past or present, evidenced from multiple sources. The case study may obtain data from direct observation or systematic interviews, as well as from public or private databases. The feature of the case study is the ability to deal with a wide variety of evidence-documents, artifacts, interviews and observations (Yin, 2003).

Considering that multiple sources of evidences is a characteristic of case study, this research followed two-stage process for data collection. In the first stage of research process, online newspaper and websites have been used to know about the level and extent of disruptions caused by COVID-19 in the RMG sector in Bangladesh. Online newspaper, a revolution for the research work (Thiel, 1998) along with websites, is a modern warehouse of information and data. Besides, archived news from online newspapers and websites provide flexibility to users to browse at their convenience. Online daily papers are moreover giving filed news so the adaptability of users to browse and stories at their claim and setting. Daily papers through advanced media are substantial sources of data, information, so researchers and scholars collect and translate information by utilizing this data. At present, researchers can utilize web not as it were assembling the information but to utilize this information to reshape their thoughts for their inquire about their research works. Tanackovic et al. (2014) have conducted that use of daily paper in inquire about, in spite of the fact that being utilized sometimes and seen not valid and dependable.

The semi-structured interviews allowed us to explore the experiences and insights of informants within the supply chain in providing materials for the garments industry in Bangladesh. In this study collected data from the manufacturing units and buying houses in Bangladesh through seven in-depth interviews with key informants including executives holding mid- to top-level management position and supply chain decision makers in both units. Each interview provided us both formal and informal data where we have some casual discussion before and after immediate the formal interviews. We have used the internal reports, fashion magazine, garments websites, meeting notes, field notes as secondary data in this study. Table 1 presents the profile of the respondents. Each respondent endured for around 55-70 min. In each interview, respondent was inquired a number of questions to explore their capabilities to develop the supply chain resilience.

\begin{tabular}{llllll}
\hline $\begin{array}{l}\text { Interview } \\
\text { number }\end{array}$ & $\begin{array}{l}\text { Organization } \\
\text { code }\end{array}$ & Informant & Informant position & $\begin{array}{c}\text { Informant } \\
\text { experience (years) }\end{array}$ & $\begin{array}{c}\text { Interview } \\
\text { length (min) }\end{array}$ \\
\hline 1 & M1 & Inf1 & Production Manager & $>20$ & 70 \\
2 & M2 & Inf2 & Production Manager & $15-20$ & 60 \\
3 & M3 & Inf3 & Sr. Merchandiser & $10-15$ & 65 \\
4 & BH1 & Inf4 & Merchandiser & $5-10$ & 55 \\
5 & BH2 & Inf5 & Merchandiser & $5-10$ & 65 \\
6 & BH3 & Inf6 & Merchandiser & $5-10$ & 60 \\
7 & BH4 & Inf7 & Sr. Merchandiser & $15-20$ & 55 \\
Note(s): $* M$ & Manufacturer, BH $=$ Buying house & & \\
\end{tabular}


The interview responses were recorded, scripted, coded and categorized to recognize the factors and sub-factors for the measurement of resilience. This research taken after the capability variables recognized by distinctive respondents and analyzed the components from Bangladesh RMG viewpoint.

\section{Findings from the case study}

\subsection{RMG sector's supply chain resilience capacity}

The fast spread of COVID-19 has affected businesses around the world making trade officials reexamine and reassess the practicality of their operations. Typically, it is particularly apparent when it comes to those in SCM where companies are continually being forced to guarantee that merchandise and supplies to reach those in require. Having to bargain with request stuns, logistics limitations, local and international shutdowns, the supply chains of companies are being required to be dependable against the scenery of unstable conditions. Most of the companies presently are considering prompt short-term effect of their supply chains with a center on getting their fulfillments done. Some of them are attending to learn a few difficult lessons from COVID-19 which can constrain them to think around the key approach to supply chains with an accentuation on building resilience. Amid the widespread period when producer found their budgetary misfortunes, government and other organizations are all of a sudden taking few activities to play down this disturbance. Producers requested policymaker to open all the industrial facilities with highest level of security for labors and employees. During the lockdown period when other sectors remain closed, they open plant with a few terms and conditions fair to play down their misfortunes.

Table 2 lists the 14 capability factors with their sub-factors (Pettit et al., 2010). This compilation provides the existing and proposed factors, responsible and status of RMG sector of their sub-factors. This gathering gives the primary itemized scientific categorization of flexibly chain strength, permitting the board to build up an arrangement of capacities adjusting their intrinsic example of vulnerabilities, as per the supply chain resilience framework.

\subsection{Findings discussion}

Garments manufacturers have been trying to find their way to remain resilient during disasters, like pandemic this time. Since there are a lot of uncertainties on both supply and demand sides, which generates tough supply and demand challenges, a combined effort including the support of government, international buyers, local organizations, garments organizations and organizations of labor rights are required. However, a concerted effort including the major stakeholders mentioned above is very unlikely, because level and dimension of interest vary among the stakeholders. Bangladesh's overdependence on clothing sector may end up being its Achilles heel. Large-scale order cancellation and postponement is causing a liquidity emergency over the division, provoking the BGMEA to advance for help, both from global buyers and the government. While the government has over and over been requesting that individuals remain at home in endeavors to contain the spread of the infection during the pandemic period during the lockdown throughout the country, BGMEA and BKMEA announced in a joint statement that factory office can open only for disburse wages and other payments during the period with the help of respective trade bodies and industrial police.

The results were obtained through interview covering the fourteen capability factors of supply chain resilience based on Petit et al. (2010). Respondents have been discussed about extravagantly at their interviews with respect to the components of fourteen sub-factors of capabilities. Table 1 appeared their supposition in see of components, mindful and status of
Supply chain resilience for RMG 


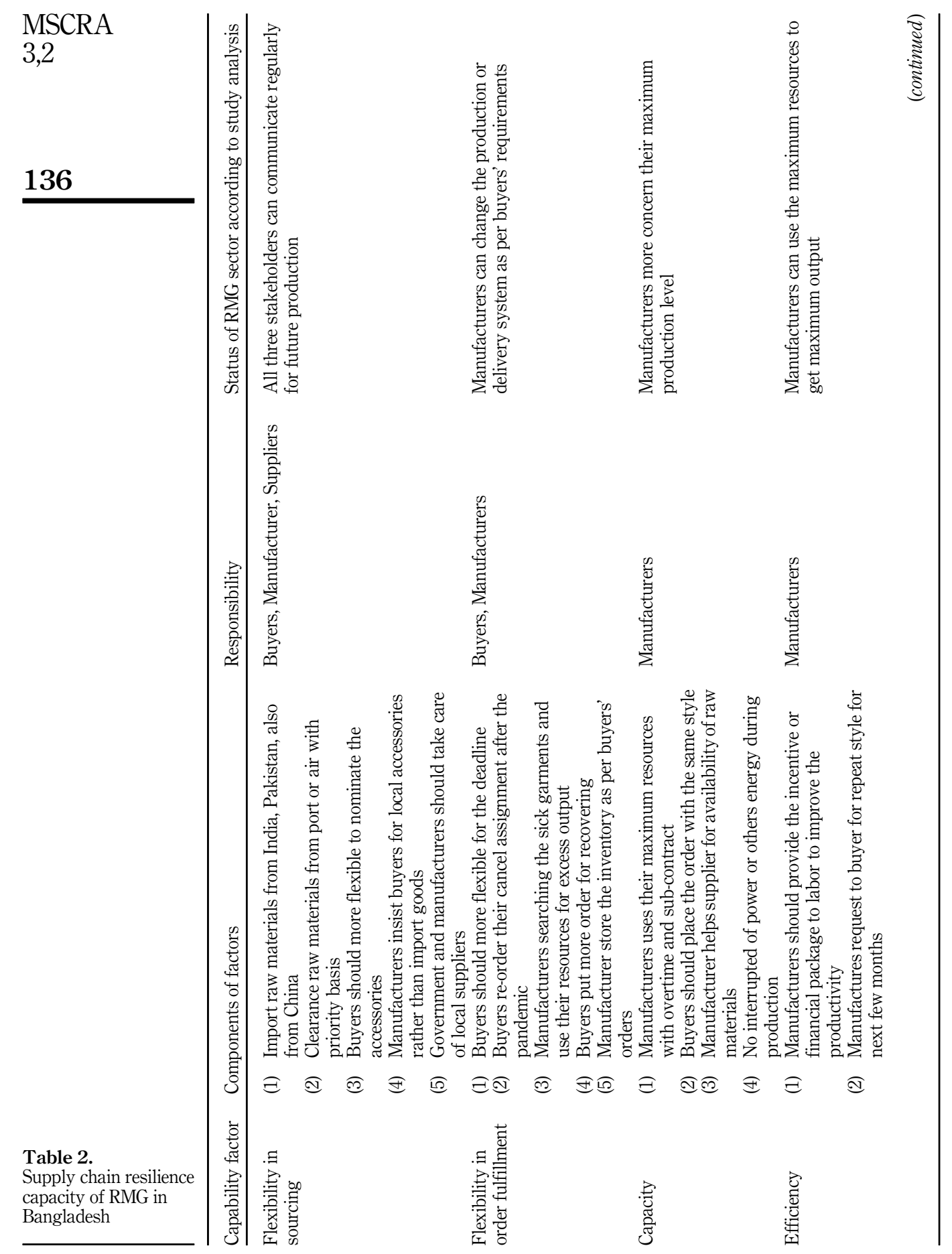




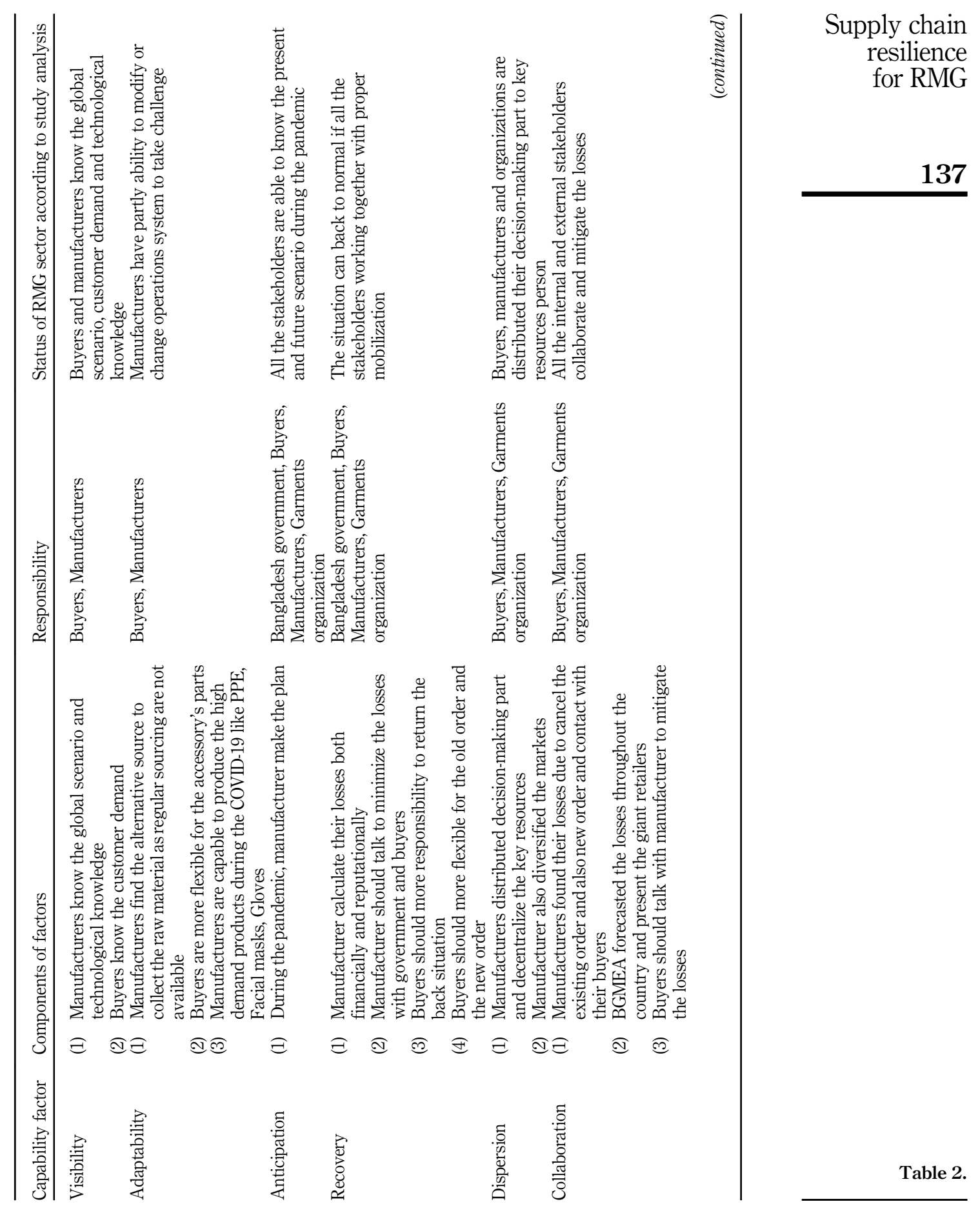




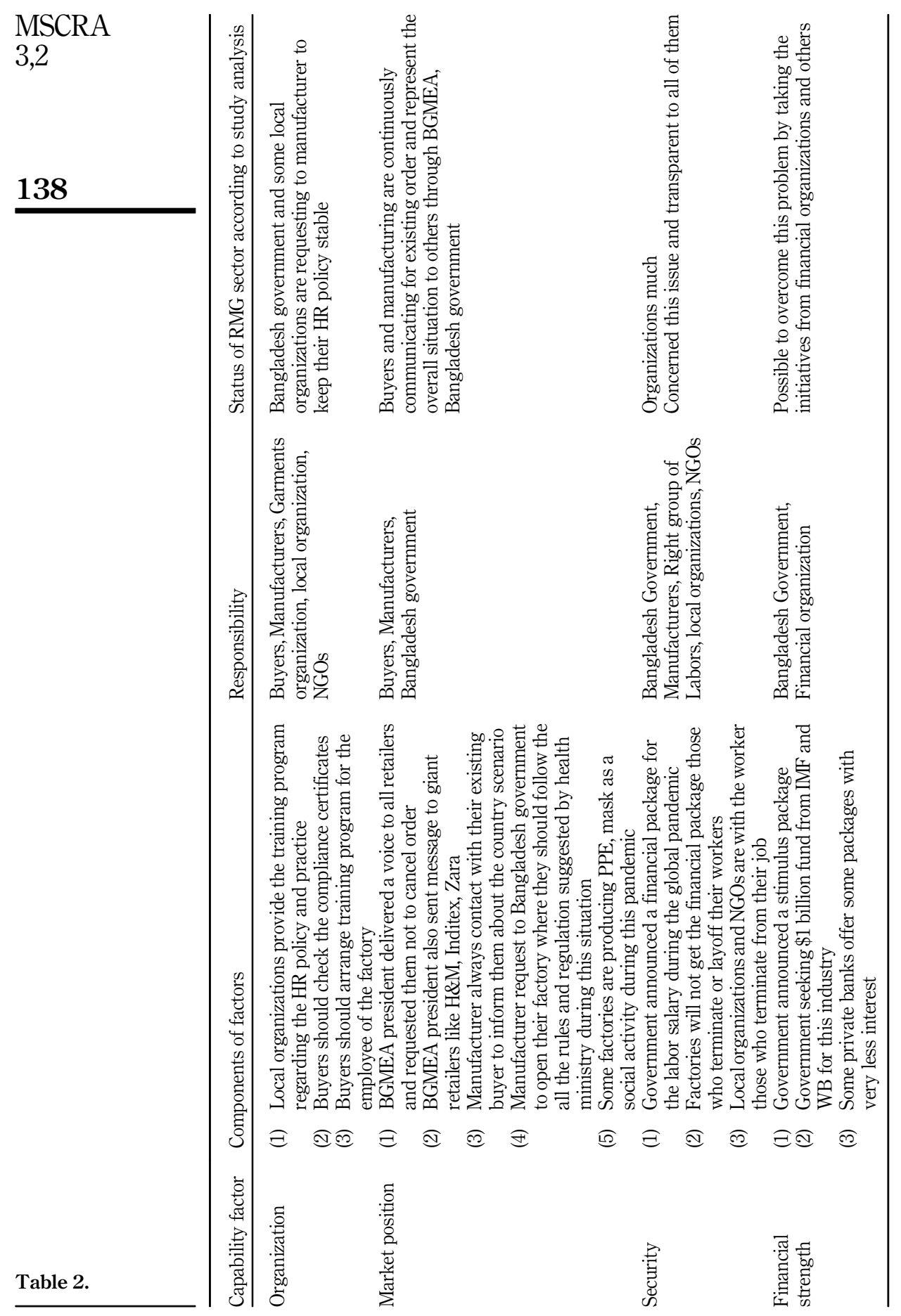


the factors. Results were then structured according to each one of the fourteen capability factors considering the responses gathered. Most of the factors are dependable with the inside partners like buyers and manufactures and a few of them are moreover dependable moreover with the outside partners like organizations, government. All the components of the capability factor have been discussed on the premise of current setting that given by the respondents. It moreover has been analyzed the roles and responsibilities of buyers, manufacturers, suppliers and other outside partner to relieve the emergency conjointly to construct up supply chain resilience.

The supply chain resilience model has extraordinary potential for giving administration knowledge into their strength, weakness, threats and needs. Manufacturers will have detailed information on their strengths by identifying high rated capability factors with their sub-factors and also identity their current resources and strengths for maximizing uses. Figure 1 shows the supply chain resilience framework which shows not only a matter of strength, it represents the balance between capabilities and vulnerabilities of the manufacturing organizations. It also shows that balanced and unbalanced resilience when vulnerabilities and capabilities do not match each other. To create a balanced resilience, it must make strong capabilities in the zones of collaboration, visibility and flexibility in order to effectively manage their interrelated operations between different levels of suppliers and customers. Figure 2 shows the measurement of resilience matrix that possible position that companies find themselves in with regard to varied levels of the quadrants. Supply chain exhibiting low capabilities with high vulnerabilities would have fragile quadrant as a disruption. For example, the current scenarios are all the factories closed due to countrywide lockdown and also orders are canceled from international buyers. Another possible attribute when all the organizations including the Bangladesh government support them whereas world scenarios will not be in favor of them or countrywide situation does not change whereas international support with them. The best possible attributes are hardy where low vulnerable with high capability. For example, the business will get strong support from both national and international, it's easy to get back. There are two other middle positions between fragile and hardy. These two positions can explore the result where the capabilities and vulnerabilities don't match each other.

The ultimate goal of the finished items is for the most part traded to the EU an American market and these rangers are unequivocally influenced and due to countrywide lockdown, even though most of the buyers are not interested to require the items which are requested. Due to eccentric circumstance, buyers made arrange a certainly crushing their one or more season instead of the standard season, as a result chain of the all the sections are influenced. In spite of the fact that a few of the buyers are committed to producers to recuperate their misfortunes mostly in numerous ways like taking the requested products gradually, put arrange more than the standard amount. Bangladesh government, BGMEA president, manufacturers are ceaselessly communicating with the worldwide buyers to share the display scenario as they accept that buyers can moderate the disturbance for the most part. In spite of the fact that governments, a few national and worldwide organizations, labor organizations are attempting to contribute different ways to play down this disturbance. People group from this trade with their encounter have communicated their concerned that it's not so simple to urge back to typical inside a really brief time with the financial and others support.

\section{Conclusion}

The COVID-19 pandemic has profoundly impacted the global supply chain and demand for the entire fashion sector. Top exporters like Bangladesh have begun feeling the warmth because of raw material sourcing difficulties and dropped orders. The performance of the 
MSCRA

3,2

RMG sector is progressively basic for an economy like Bangladesh. It is basic to investigate the demand side situation by breaking down the European, US and developing markets for apparel export. The concept of strength is broader in scope than coordinates SCM, coherence planning, risk administration or an amalgamation of all of these disciplines. In spite of the publication of a couple of considers on capability factors for supply chain resilience during the global pandemic, a considerable and dependable measuring factors was still missing. The supply chain resilience framework herein proposed is the pionery on characterizing the resilience in terms of identifiable and quantifiable factors.

This study in this way created the components of all the sub-factors of capabilities factors in the midst of the noble infection. The framework recognizes that have to be adjust to adjusted and unequal resilience with the capability's components and inherent vulnerabilities of the supply chain plan and the environment in which it works. By developing the resilience matrix with the four conceivable positions, companies can discover themselves with their capability's components and inborn vulnerabilities. It can be adjusted for other industrial sectors in other nations with suitable contextualization through subjective ponders. To this conclusion, this ponder makes a critical commitment to the literature.

This investigation was conducted inside a particular industry in one nation, Bangladesh. Our respondents are inundated in Bangladeshi culture, which is characterized by high control separate and high in-group collectivism (House et al., 2004). Subsequently, our information will reflect the national social predisposition. Replications in other settings would increase confidence within the inquire about demonstrate. Encourage surveying the generalizing of the components of capabilities created in this thing about to other commerce situations, for case, testing the components in other countries would be worthwhile. The extend of components in our paper has been contextualized for a particular nation.

\subsection{Practical and theoretical implications}

This research reflects a wide view of the literature review about resilience components of the SCM within the fashion industry, especially related to relation between capabilities and vulnerabilities. From the unbeneficial firms to successful ones, resilience approach was one of the keys. The research identified the capabilities components those can fill this expertise gap and providing the fundamental knowledge to handle those rising disturbances way better. Management in garments industry must advance a center on resilience as well as learning from current occasions to make strides decision-making. Moreover, this study shows the importance in effectively coordinating capabilities and vulnerabilities in SCM to extend competitiveness.

The framework recognized the balanced and unbalanced strength with the capability's components and characteristics vulnerabilities of the supply chain arrange and the environment in which it works. Companies can find themselves with their capability's components and natural vulnerabilities from the resilience network with the four conceivable positions. The evidences from this study may effectively support supply chain's practitioners on a more assertive decision-making with regards capabilities aspects of supply chain's resilience.

In terms of theoretical implications, this research brings relevant contribution with regards the resilience management in supply chains. This lesson learned from the COVID-19 context, especially from RMG industry in Bangladesh, provides insights in terms on how capabilities management in the face of vulnerabilities may impact directly on the supply chain performance. Although this study has its limitations in terms of generalization, it shows important drivers to future empirical and broader studies, being the basis for future quantitative studies related to the aspects of capabilities and vulnerabilities on supply chain' resilience. 


\section{References}

Ahmed, N. (2009), "Sustaining ready-made garment exports from Bangladesh", Journal of Contemporary Asia, Vol. 39 No. 4, pp. 597-618, doi: 10.1080/00472330903076891.

Akhter, S., Rutherford, S. and Chu, C. (2019), "Sufferings in silence: violence against female workers in the ready-made garment industry in Bangladesh: a qualitative exploration”, Women's Health, Vol. 14, pp. 1-10, doi: 10.1177/1745506519891.

Ashraf, H. and Prentice, R. (2019), "Beyond factory safety: labor unions, militant protest, and the accelerated ambitions of Bangladesh's export garment industry", Dialectical Anthropology, resilience for RMG Vol. 43 No. 1, pp. 93-107, doi: 10.1007/s10624-018-9539-0.

Banga, K. and te Velde, D.W. (2020), Cambodia, COVID-19 and Inclusive Digital Transformation: A Sevenpoint Plan, Supporting Economic Transformation, London.

BGMEA (2020), The Parel Story: January-March 2020, Pathways from Promise. Bangladesh Garments Manufacturers and Exporters Association, available at: https://www.bgmea.com.bd/media/ newsletters/App_Story_Jan_March_2020/App_Story_Jan_March_2020.pdf (accessed 24 April 2020).

Biswas, R.K., Huq, S., Afiaz, A. and Khan, H.T. (2020), "A systematic assessment on COVID-19 preparedness and transition strategy in Bangladesh", Journal of Evaluation in Clinical Practice, Vol. 26 No. 6, pp. 1599-1611, doi: 10.1111/jep.13467.

Brusset, X. and Teller, C. (2017), "Supply chain capabilities, risks, and resilience", International Journal of Production Economics, Vol. 184, pp. 59-68, doi: 10.1016/j.ijpe.2016.09.008.

Brydges, T. and Hanlon, M. (2020), "Garment worker rights and the fashion industry's response to COVID-19”, Dialogues in Human Geography, Vol. 2043820620933851, doi: 10.1177/ 2043820620933851.

Bryman, A. and Bell, E. (2007), Business Research Methods, 4th ed., Oxford University Press, Oxford.

Büyüközkan, G. and Göçer, F. (2018), "Digital Supply Chain: literature review and a proposed framework for future research", Computers in Industry, Vol. 97, pp. 157-177, doi: 10.1016/j. compind.2018.02.010.

Carvalho, H., Cruz-Machado, V. and Tavares, J.G. (2012), "A mapping framework for assessing supply chain resilience”, International Journal of Logistics Systems and Management, Vol. 12 No. 3, pp. 354-373.

Christopher, M. and Peck, H. (2004), "Building the resilient supply chain”, The International Journal of Logistics Management, Vol. 15 No. 2, pp. 1-14, doi: 10.1108/09574090410700275.

Chowdhury, M.M.H. and Quaddus, M. (2017), "Supply chain resilience: conceptualization and scale development using dynamic capability theory", International Journal of Production Economics, Vol. 188, pp. 185-204, doi: 10.1016/j.ijpe.2017.03.020.

De Sá, M.M., de Souza Miguel, P.L., de Brito, R.P. and Pereira, S.C.F. (2019), "Supply chain resilience: the whole is not the sum of the parts", International Journal of Operations and Production Management, Vol. 40 No. 1, pp. 92-115, doi: 10.1108/IJOPM-09-2017-0510.

De Sousa Jabbour, A.B.L., Jabbour, C.J.C., Hingley, M., Vilalta-Perdomo, E.L., Ramsden, G. and Twigg, D. (2020), "Sustainability of supply chains in the wake of the coronavirus (COVID-19/SARSCoV-2) pandemic: lessons and trends", Modern Supply Chain Research and Applications, Vol. 2 No. 3, pp. 117-122, doi: 10.1108/MSCRA-05-2020-0011.

FEAR WEAR (2020), "Covid-19: garment industry coalition calls for urgent action", available at: https://www.fairwear.org/stories/covid-19-garment-industry-coalition-calls-for-urgentactionhttps://fashionunited.uk/news/business/bangladesh-set-to-lose-6-billion-dollars-in-exportrevenue/2020040148272 (accessed 19 April 2020).

Frederico, G.F. (2020), "Achieving more resiliency against COVID-19 outbreak. Supply chain management review - SCMR", available at: https://www.scmr.com/article/in_times_of_ coronavirus_maturity_in_supply_chain_management_really_mat. 
MSCRA

3,2
Frederico, G.F., Garza-Reyes, J.A., Anosike, A. and Kumar, V. (2019), "Supply Chain 4.0: concepts, maturity and research agenda”, Supply Chain Management, Vol. 25 No. 2, pp. 262-282, doi: 10. 1108/SCM-09-2018-0339.

Hossain (2019), "Supply Chain apparel industry in Bangladesh, Bangladesh supply chain review", available at: http://www.bscms.com.bd/sites/default/files/Supply Chain Management in Apparel Industry - Shakhawat Hossain.pdf (accessed 20 April 2020).

Hosseini, S., Ivanov, D. and Dolgui, A. (2019), "Review of quantitative methods for supply chain resilience analysis", Transportation Research Part E: Logistics and Transportation Review, Vol. 125, pp. 285-307, doi: 10.1016/j.tre.2019.03.001.

House, R.J., Hanges, P.J., Javidan, M., Dorfman, P.W. and Gupta, V. (Eds) (2004), Culture, Leadership, and Organizations: The GLOBE Study of 62 Societies, Sage Publications.

Ivanov, D. and Dolgui, A. (2020), "Viability of intertwined supply networks: extending the supply chain resilience angles towards survivability. A position paper motivated by COVID-19 outbreak", International Journal of Production Research, Vol. 58 No. 10, pp. 2904-2915, doi: 10. 1080/00207543.2020.1750727.

Jüttner, U. and Maklan, S. (2011), "Supply chain resilience in the global financial crisis: an empirical study", Supply Chain Management: An International Journal, Vol. 16 No. 4, pp. 246-259, doi: 10. 1108/13598541111139062.

Kabir, H., Maple, M. and Usher, K. (2020), "The impact of COVID-19 on Bangladeshi readymade garment (RMG) workers", Journal of Public Health, Vol. 43 No. 1, pp. 47-52.

Kelly, A. (2020), Garment Workers Face Destitution as Covid-19 Closes Factories, Theguardian.Com, available at: https://www.theguardian.com/globaldevelopment/2020/mar/19/garment-workersface-destitution-as-covid-19-closes-factories.

Khan, M.A. and Milne, G. (2019), "Global Governance, neoliberalism and national responses: the case of Bangladesh's ready-made garment (RMG) sector", Development Policy Review, Vol. 37 No. S2, pp. O230-O247, doi: 10.1111/dpr.12383.

Lee, H.L. (2004), “The triple-A supply chain”, Harvard Business Review, Vol. 82 No. 10, pp. 102-113.

Liu, X., Mishra, A., Goldstein, S. and Sinha, K.K. (2019), "Toward improving factory working conditions in developing countries: an empirical analysis of Bangladesh ready-made garment factories", Manufacturing and Service Operations Management, Vol. 21 No. 2, pp. 379-397, doi: $10.1287 / \mathrm{msom} .2017 .0679$.

McKibbin, W.J. and Fernando, R. (2020), The Global Macroeconomic Impacts of COVID-19: Seven Scenarios, The Brookings Institution, Washington DC, available at: https://www.brookings. edu/research/the-global-macroeconomic-impacts-of-covid-19-seven-scenarios/ (accessed 7 June 2020).

Menzel, A. and Woodruff, C. (2019), Gender Wage Gaps and Worker Mobility: Evidence from the Garment Sector in Bangladesh (No. W25982), National Bureau Economic Research, Cambridge, Massachusetts.

Napoleone, A. and Prataviera, L.B. (2020), "Reconfigurable manufacturing: lesson learnt from the COVID-19 outbreak", IFIP International Conference on Advances in Production Management Systems, Cham, Springer, pp. 457-465, doi: 10.1007/978-3-030-57993-7_52.

Papadopoulos, T., Gunasekaran, A., Dubey, R., Altay, N., Childe, S.J. and Fosso-Wamba, S. (2017), "The role of Big Data in explaining disaster resilience in supply chains for sustainability", Journal of Cleaner Production, Vol. 142, pp. 1108-1118, doi: 10.1016/j.jclepro.2016.03.059.

Paul, S.K. and Chowdhury, P. (2020), "A production recovery plan in manufacturing supply chains for a high-demand item during COVID-19", International Journal of Physical Distribution and Logistics Management, Vol. 51 No. 2, pp. 104-125, doi: 10.1108/IJPDLM-04-2020-0127.

Pettit, T.J., Fiksel, J. and Croxton, K.L. (2010), "Ensuring supply chain resilience: development of a conceptual framework", Journal of Business Logistics, Vol. 31 No. 1, pp. 1-21, doi: 10.1002/j.21581592.2010.tb00125.x. 
Pettit, T.J., Croxton, K.L. and Fiksel, J. (2019), "The evolution of resilience in supply chain management: a retrospective on ensuring supply chain resilience", Journal of Business Logistics, Vol. 40 No. 1, pp. 56-65, doi: 10.1111/jbl.12202.

Ponomarov, S.Y. and Holcomb, M.C. (2009), "Understanding the concept of supply chain resilience", International Journal of Logistics Management, Vol. 20 No. 1, pp. 124-143, doi: 10.1108/ 09574090910954873.

Rubbio, I., Bruccoleri, M., Pietrosi, A. and Ragonese, B. (2019), "Digital health technology enhances resilient behaviour: evidence from the ward", International Journal of Operations and Production Management, Vol. 40 No. 1, pp. 34-67, doi: 10.1108/IJOPM-02-2018-0057.

Sabahi, S. and Parast, M.M. (2019), "Firm innovation and supply chain resilience: a dynamic capability perspective", International Journal of Logistics Research and Applications, Vols 1-16, pp. 254-269, doi: 10.1080/13675567.2019.1683522.

Sakamoto, M., Begum, S. and Ahmed, T. (2020), "Vulnerabilities to COVID-19 in Bangladesh and a reconsideration of sustainable development goals", Sustainability, Vol. 12 No. 13, p. 5296, doi: 10. 3390/su12135296.

Scholten, K., Stevenson, M. and van Donk, D.P. (2019), "Dealing with the unpredictable: supply chain resilience", International Journal of Operations and Production Management, Vol. 40 No. 1, pp. 1-10, doi: 10.1108/IJOPM-01-2020-789.

Sen, S., Antara, N., Sen, S. and Chowdhury, S. (2020), The unprecedented Pandemic 'COVID-19' Effect on the Bangladesh apparel workers by shivering the apparel supply chain, Vol. 11 No. 3, pp. 1-20, available at SSRN 3598542.

Stevenson, W.J. and Sum, C.C. (2014), Operations Management, McGraw-Hill/Irwin, New York, NY, Vol. 10.

Talapatra, S., Uddin, M.K., Antony, J., Gupta, S. and Cudney, E.A. (2019), "An empirical study to investigate the effects of critical factors on TQM implementation in the garment industry in Bangladesh”, International Journal of Quality and Reliability Management, Vol. 37 Nos 9/10, pp. 1209-1232, doi: 10.1108/IJQRM-06-2018-0145.

Tanacković, S.F., Krtalić, M. and Lacović, D. (2014), "Newspapers as a research source: information needs and information seeking of humanities scholars", 80th IFLA General Conference and Assembly, Lyon, IFLA World Library and Information Congress, available at: https://www.ifla. org/files/assets/newspapers/Geneva_2014/s6-lacovic-en.pdf.

Tang, C.S. (2006), "Robust strategies for mitigating supply chain disruptions", International Journal of Logistics: Research and Applications, Vol. 9 No. 1, p. 33, doi: 10.1080/13675560500405584.

Thiel, S. (1998), “The online newspaper: a postmodern medium”, Journal of Electronic Publishing, Vol. 4 No. 1, doi: 10.3998/3336451.0004.110.

Uddin, M.B. and Akhter, B. (2019), "Antecedents and outcomes of supply chain management in Bangladesh”, Modern Supply Chain Research and Applications, Vol. 1 No. 1, pp. 68-87, doi: 10. 1108/MSCRA-02-2019-0007.

Vanpoucke, E. and Ellis, S.C. (2019), "Building supply-side resilience-a behavioural view", International Journal of Operations and Production Management, Vol. 40 No. 1, pp. 11-33, doi: 10.1108/IJOPM-09-2017-0562.

Van Hoek, R. (2020), "Research opportunities for a more resilient post-COVID-19 supply chain - closing the gap between research findings and industry practice", International Journal of Operations and Production Management, Vol. ahead-of-print No. ahead-of-print, doi: 10.1108/IJOPM-03-2020-0165.

Voss, C., Tsikriktsis, N. and Frohlich, M. (2002), "Case research in operations management", International Journal of Operations and Production Management, Vol. 22 No. 2, pp. 195-219, doi: $10.1108 / 01443570210414329$.

WHO (2020), Naming the Coronavirus Disease (COVID-19) and the Virus that Causes it, available at: https://www.who.int/emergencies/diseases/novel-coronavirus-2019/technical-guidance/namingthe-coronavirus-disease-(covid-2019)-and-the-virus-that-causes-it (accessed 25 April 2020).

Supply chain resilience for RMG 
MSCRA

3,2

144

Wu, F., Zhao, S., Yu, B., Chen, Y.-M., Wang, W., Song, Z.-G., Hu, Y., Tao, Z.-W., Tian, J.-H., Pei, Y.-Y., Yuan, M.-L., Zhang, Y-L., Dai, F.-H., Liu, Y., Wang, Q.-M., Zheng, J.-J., Xu, L., Holmes, E.C. and Zhang, Y.-Z. (2020), "A new coronavirus associated with human respiratory disease in China", Nature, Vol. 579 No. 7798, pp. 265-269, doi: 10.1038/s41586-020-2008-3.

Yin, R. (2003), Case Study Research: Design and Methods, 3rd ed., Sage Publications, London, Vol. 3.

\section{About the authors}

Mohammad Ali is an Assistant Professor of Operations and Supply Chain Management at American International University-Bangladesh. Mohammad conducts research on commercial supply chain management and humanitarian supply chain management. Currently he is doing the project on garments industry in Bangladesh and coordination of different organizations in Rohingya refugee in Bangladesh. He teaches operations management, project management and supply chain management. Mohammad earned his master in mechanical engineering from Karlstad University, Sweden. Mohammad Ali is the corresponding author and can be contacted at: aliss348@gmail.com

Syed Mahbubur Rahman is an associate professor at American International University-Bangladesh (AIUB). He earned his doctorate in global environmental studies from Kyoto University, Japan. He has also been educated in Germany, Thailand and Bangladesh, while has served in various academic and research institutes in Germany, Oman and Bangladesh. He has published numerous articles and book chapters about renewable energy, climate finance, climate change adaptation and health management issues. His research interests also include adaptation to drought, supply chain resilience, adaptationmitigation integration and environmental policy.

Guilherme F. Frederico is a professor of Operations and Supply Chain Management-SCMat Federal University of Paraná - UFPR - School of Management, Brazil. He is also Professor and Researcher at Information Management Department on MSc and $\mathrm{PhD}$ programs. He has been working in collaboration with the Centre for Supply Chain Management at University of Derby-UK as Visiting Research Professor. His research interests and expertise are related to SCM Maturity and Resilience, Performance Measurement in Supply Chains, Knowledge Management in Operations and Supply Chains, Project Management, Industry 4.0 and Supply Chain 4.0. Guilherme F. Frederico holds PhD and MS.C in Industrial Engineering and B.Eng. in Civil Engineering. Besides academic experience, he has previous industrial experience having worked for more than 10 years in global companies on strategic positions of SCM.

For instructions on how to order reprints of this article, please visit our website:

www.emeraldgrouppublishing.com/licensing/reprints.htm

Or contact us for further details: permissions@emeraldinsight.com 